The Effect of Gymnastics on the Level of Motor Intelligence and the Performance of Some Motor Skills for Children with Mental Disabilities

*Ass. Prof Azza Aly Kassem Lotfy

Introduction and Research Problem:

Behavioral problems associated with children with learning disabilities are a concern for people around them, both at home and at school. Over-activity is a major problem for children with learning disabilities because of its negative social, emotional, behavioral and physical impact.

The current scientific and practical boom is witnessing a critical interest in children with special needs and their attempt to help them adapt to the society in which they live. People with special needs have been severely disabled by their ability to do their jobs in life as well as ordinary people.

Attention to these groups, which suffer from a lack of physical, sensory, mental or behavioral abilities, through the preparation of special educational and rehabilitation programs to exploit these capacities and develop them to the maximum extent possible, which necessitates changing the societal perception of this (18: 7) as a part of the human revolution and to make full use of it.

People with special needs represent a large proportion of the population. International bodies and institutions indicate an increasing growth in the number of people with disabilities. According to the World Health Organization (WHO), $10 \%$ to $12 \%$ of the population of developing countries are disabled and the mentally disabled Or qualitative in one form or another Disabilities other than lack of general intelligence and the degree of disability is an important factor in learning (18-1)

Hence, the importance of psychosocial, mental, motor

"Assistant Professor in Department of Rhythmic Exercises and Artistic Gymnastics, Faculty of Physical Education for Girls, Gizera, Giza, Helwan University 
and social care for the mentally handicapped in order to increase compatibility and modify behavior, whether with oneself or with others, and transform them into productive energy.

In this regard,. Subhi (2000) adds that when providing sports activities for mental disabilities, especially those in which they use their senses And their feelings and muscles, this helps them to improve their physical performance and motor compatibility and may affect effectively modify their view of their parents in a positive direction. (2: 9)

Children with dynamic intelligence are sports-oriented athletes who have the ability to control the body's activity and movements properly.

This intelligence is linked to motor skills and physical attributes, which in turn require one or more sensory receptor patterns and the efficiency of sensory receptors associated with the pattern The performance of the child's movement refers to its kinetic intelligence, through which its degree can be judged in sports practice $(21: 19)$
Gymnastics is a kind of self-indulgent sport that draws children's attention to practice, which is beneficial to them in terms of their acquisition of good strength and educational values, as well as the development of physical, skill, psychological and social abilities, giving them the ability to create, 4 )

Gymnastics provides an opportunity for children to create the ability to innovate and to achieve satisfaction and happiness when successful in the performance of formations and the implementation of the movements of constituents, Which leads to the development of the ability to reflect consistency and continuity and harmony and balance, and also develops awareness of the need for strength and skin to complete some movements the innovative gymnastics. (94:14)

Entitled "The Effect of a Proposed Kinetic Education Program on Some Behavioral Disabilities and Cognitive Cognition" (6). (15) Entitled

"The Effect of the Gymnastics Program on Physical Adaptation, Attention Disorders and Social 
Interactions of Autistic Children, and Manar Shahin's Study (16), entitled Effect of a Proposed Program for Gymnastics and Obstacles to Reduce Allen Framework and some excess capacity psychomotor for children learning difficulties.

In view of the importance of sports education programs in the life activities of children, there have been many programs of interest in this category, Which is the spread of schools and sports clubs to help them to output their capacity to the maximum possible for each individual's abilities and this prompted the researcher to think about the preparation of this research in an attempt to identify the impact A program for gymnastics at the level of motor intelligence and the performance of some motor skills for children with mental disabilities.

\section{Search Goal:}

The aim of the research is to identify the effect of gymnastics on the level of motor intelligence and the performance of some motor skills for children with mental disabilities.
Research hypotheses:

There are statistically significant differences between the pre and post measures in the level of motor intelligence of the disabled and for the benefit of telemetry.

-There are statistically significant differences between the pre and post measures in the level of motor skills of mentally handicapped children who are capable of learning in favor of telemetry.

\section{Search procedures:}

Research Methodology:

The researcher used the experimental method using a single experimental group by following the post-pre measurement to suit the nature of the research

\section{Second: Society and} Research Sample:

The research community was chosen from mentally disabled students at the School for Intellectual Education in Cairo Governorate under the supervision of Sayda Zeinab for the academic year 2016/2017 who are capable of learning and who are intelligent (between 50\% $70 \%$ ), mental age (5-7 years) The research community reached (28) students and 8 
students were excluded. The researcher has set the following conditions for the Research sample:
Table (1)

-Do not have other disabilities associated with mental disability.

-Regularity to go to school without interruption.

Arithmetic pre, pre, standard deviation, and torsion coefficient for variables Motor skills and motor intelligence $(\mathbf{N}=\mathbf{2 0})$

\begin{tabular}{l|c|c|c|c}
\hline \hline \multicolumn{1}{c|}{ Variables } & SMA & Mediator & $\begin{array}{c}\text { standard } \\
\text { deviation }\end{array}$ & $\begin{array}{c}\text { Torsion } \\
\text { coefficient }\end{array}$ \\
\hline \hline Development rates \\
\hline Mental age & 5.87 & 5.80 & 0.65 & 0.323 \\
\hline Age & 10.21 & 10.20 & 0.22 & 0.136 \\
\hline Height & 143.28 & 143.00 & 4.36 & 0192 \\
\hline Weight & 44.51 & 44.50 & 2.54 & 0.011 \\
\hline \hline
\end{tabular}

skillful variables

\begin{tabular}{l|c|c|c|c}
\hline \hline $\begin{array}{l}\text { Rolling front } \\
\text { Rounded }\end{array}$ & 2.21 & 2.20 & 0.21 & 0.142 \\
$\begin{array}{l}\text { The front roll and } \\
\text { the body are free }\end{array}$ & 2.18 & 2.10 & 0.11 & 2.18 \\
\hline $\begin{array}{l}\text { Instantaneous stand } \\
\text { On the hands }\end{array}$ & 2.63 & 2.50 & 0.35 & 1.114 \\
\hline $\begin{array}{l}\text { Rolling back Rounded } \\
\text { Motor intelligence }\end{array}$ & 2.21 & 2.20 & 0.52 & 0.0576 \\
\hline Drop the ball & 83.21 & 83.20 & 2.65 & 0.0113 \\
\hline Roll around the circle & 38.21 & 38.20 & 1.17 & 0.0256 \\
\hline Color ruler and hands & 2.28 & 2.25 & 0.25 & 0.360 \\
\hline Sound and movement & 3.48 & 3.45 & 0.61 & 0.147 \\
\hline Walk to the circle & 1.48 & 1.45 & 0.22 & 0.409 \\
\hline \hline
\end{tabular}

It is clear from Table (2) that the torsion coefficients Ranged between $(+3,-3)$ indicating that they are located within the pre curve and thus the sample is distributed Third: Data collection tools: 1-Records:
The records of students enrolled in the school of intellectual education in the area of Sayeda Zeinab for the academic year 2016/2017 were used to obtain data for the individuals of the research sample in terms of the number 
of students in the study sample.

\section{2-Forms}

\section{Registration forms:}

The researcher designed a form to record the results of the tests under consideration.

B. An expert consultation questionnaire on the content of the program

The researcher presented a questionnaire to explore the opinion of experts on the content of the proposed program using gymnastics games - program period number of units per week - unit time.

\section{r-Research tools}

First:

\section{Hardware and tools:}

- Resistameter for measurement of height and weight.

-Chalk - Measuring tape - Stop clock - Balloons - Plastic balls - Hoops - Sling - Swedish seats

- Cones - Mattresses

\section{Second:}

The battery of motor intelligence for the mentally disabled:

He designed the battery of motor intelligence Essam El-Din Shaaban Ali et al. (2008). (13) Some of the foundations for building this battery have been reached. The battery includes five tests:

1-Drop the ball (centimeter)

$r$-Roll around the circle (second)

$r$-Colored ruler and hands (number)

s-Sound and movement (second)

- Walking to the circle (number)

\section{Third:}

Evaluation of the level of motor performance by the arbitrators:

A group of arbitrators was selected to evaluate the level of motor performance of children with mental disabilities who are able to learn in motor skills in the gymnastics under consideration. A questionnaire was distributed including the movements to be evaluated.

\section{Program Content:}

The specialized scientific references (1), (2), (3), she identified the appropriate games for the games gymnasium for the nature of the mentally handicapped, and then they were presented to the professors and experts In the fields of exercise, physiology, psychology and the mentally handicapped in order to 
determine the suitability of the research sample,

Its correlation and its impact on the variables under study, as well as the total period of the program, the number of

\section{Table (2)}

Distribute the content of the proposed program for gymnastics $N=10$

\begin{tabular}{l|c|c}
\hline \hline Program content & $\begin{array}{c}\text { Experts } \\
\text { opinions }\end{array}$ & Percentage \\
\hline \hline Total time period of the program & weeks 10 & $100 \%$ \\
\hline Number of training units per week & 3 units & $90 \%$ \\
\hline $\begin{array}{l}\text { The time of the daily training } \\
\text { module }\end{array}$ & 40 minutes & $85 \%$ \\
\hline \hline
\end{tabular}

Table (6) shows that it was found that the total period of time (10) weeks by (3) units per week (40) minutes per unit. Daily module parts:

Warm-up: (5 s)

The aim is to fully prepare the parts of the body in preparation for the main part, where the researcher took care to be the performance in a collective and in the form of competitions with the use of some tools of different shapes and sizes and colors (such as plastic bottles- mattresses sponge - balloons) Main part: (30 s) training units per week and the daily training unit time. The training program was modified according to their opinions and table (5)

So:
The exercises have a total duration of 10 weeks with 3 training units per week (Saturday - Monday Wednesday). The units were implemented through the physical education classes on Saturday, Monday, while the third share was taught through the share of activity and therefore was provided three weekly classes.

Closing (5 s) aims to return the body's organs to the normal state.

View and discuss the results: First: View results: 
Table (3)

The significance of the differences between the pre and post measurements of the sample in the motor intelligence under study in the non-parametric Wilcoxon method $\mathrm{N}=12$

\begin{tabular}{|c|c|c|c|c|c|c|c|c|}
\hline \multirow{2}{*}{\multicolumn{2}{|c|}{ Variables }} & \multirow{2}{*}{$\begin{array}{l}\text { Measure } \\
\text { unit }\end{array}$} & \multicolumn{2}{|c|}{ Pre measure } & \multicolumn{2}{|c|}{ Post measure } & \multirow{2}{*}{$\begin{array}{c}\text { Value } \\
z\end{array}$} & \multirow{2}{*}{$\begin{array}{c}\text { Significance } \\
\text { level }\end{array}$} \\
\hline & & & M & $\mathrm{E}$ & M & $\mathrm{E}$ & & \\
\hline \multirow{5}{*}{$\begin{array}{l}\text { Motor } \\
\text { intelligence }\end{array}$} & $\begin{array}{l}\text { Drop the } \\
\text { ball }\end{array}$ & $\mathrm{Cm}$ & 83.21 & 2.65 & 110.32 & 2.11 & 3.28 & Indicated \\
\hline & $\begin{array}{l}\text { Roll around } \\
\text { the circle }\end{array}$ & $\mathrm{S}$ & 38.21 & 1.17 & 31.25 & 1.02 & 3.21 & Indicated \\
\hline & $\begin{array}{l}\text { Color } \\
\text { ruler and } \\
\text { hands }\end{array}$ & No & 2.28 & 0.25 & 4.28 & 0.24 & 3.96 & Indicated \\
\hline & $\begin{array}{l}\begin{array}{l}\text { Sound } \\
\text { and } \\
\text { movement }\end{array} \\
\end{array}$ & $S$ & 3.48 & 0.61 & 1.38 & 0.32 & 3.17 & Indicated \\
\hline & $\begin{array}{l}\text { Walk to } \\
\text { the circle }\end{array}$ & No & 1.48 & 0.22 & 3.21 & 0.18 & 3.64 & Indicated \\
\hline
\end{tabular}

-The value of $\mathrm{z}$ to denote the parties at the level of $0.05=1.96$

It is clear from Table (3) that there are statistically significant differences between the pre and post measurements of the sample in question in the motor intelligence in question in the direction of post measure.

Table (4)

Percentage improvement between the pre and post measurements of the sample in question Motor intelligence is under investigation $\mathrm{N}=12$

\begin{tabular}{|c|c|c|c|c|c|c|}
\hline \multicolumn{2}{|c|}{ Variables } & $\begin{array}{c}\text { Measure } \\
\text { unit }\end{array}$ & $\begin{array}{c}\text { Pre } \\
\text { measure }\end{array}$ & $\begin{array}{c}\text { Post } \\
\text { measure }\end{array}$ & $\begin{array}{c}\text { Differences } \\
\text { between the }\end{array}$ & $\begin{array}{c}\text { improvement } \\
\text { rate }\end{array}$ \\
\hline \multirow{5}{*}{$\begin{array}{l}\text { Motor } \\
\text { intelligence }\end{array}$} & $\begin{array}{l}\text { Drop } \\
\text { the ball }\end{array}$ & $\mathrm{Cm}$ & 83.21 & 110.32 & 27.11 & $24.57 \%$ \\
\hline & $\begin{array}{l}\text { Roll } \\
\text { around } \\
\text { the circle }\end{array}$ & $\mathrm{S}$ & 38.21 & 31.25 & 6.96 & $18.21 \%$ \\
\hline & $\begin{array}{l}\text { Color } \\
\text { ruler and } \\
\text { hands }\end{array}$ & No & 2.28 & 4.28 & 2.00 & $87.71 \%$ \\
\hline & $\begin{array}{l}\begin{array}{l}\text { Sound and } \\
\text { movement }\end{array} \\
\end{array}$ & $\mathrm{S}$ & 3.48 & 1.38 & 2.10 & $60.34 \%$ \\
\hline & $\begin{array}{l}\text { Walk to the } \\
\text { circle }\end{array}$ & No & 1.48 & 3.21 & 1.73 & $53.89 \%$ \\
\hline
\end{tabular}


Table (4) shows that the percentage of improvement of the percentage of pre and post measurements of the sample in question in the motor intelligence in question ranged between (18.21\%: 87.71\%) indicating that the program has a positive effect on the variables under consideration.

Table (5)

The significance of the differences between the pre and post measurements of the sample under study in the skill performance under the Wilcoxon non-barometric method $\mathrm{N}=12$

\begin{tabular}{|c|c|c|c|c|c|c|c|c|}
\hline \multirow{2}{*}{\multicolumn{2}{|c|}{ Variables }} & \multirow{2}{*}{$\begin{array}{l}\text { Measure } \\
\text { unit }\end{array}$} & \multicolumn{2}{|c|}{$\begin{array}{c}\text { Pre } \\
\text { measure }\end{array}$} & \multicolumn{2}{|c|}{$\begin{array}{c}\text { Post } \\
\text { measure }\end{array}$} & \multirow{2}{*}{$\begin{array}{c}\text { Value } \\
z\end{array}$} & \multirow{2}{*}{$\begin{array}{c}\text { Significance } \\
\text { value }\end{array}$} \\
\hline & & & M & E & M & E & & \\
\hline \multirow{4}{*}{$\begin{array}{l}\text { Performance } \\
\text { skill }\end{array}$} & $\begin{array}{l}\text { Rolling front } \\
\text { Rounded }\end{array}$ & Degree & 2.21 & 0.21 & 3.68 & 0.69 & 3.01 & Indicated \\
\hline & $\begin{array}{l}\text { The front roll } \\
\text { and the body } \\
\text { are free }\end{array}$ & Degree & 2.18 & 0.11 & 3.88 & 0.52 & 3.21 & Indicated \\
\hline & $\begin{array}{l}\text { Instantaneous } \\
\text { stand } \\
\text { On the hands }\end{array}$ & Degree & 2.63 & 0.35 & 3.94 & 0.47 & 3.15 & Indicated \\
\hline & $\begin{array}{l}\text { Rolling back } \\
\text { Rounded }\end{array}$ & Degree & 2.21 & 0.52 & 3.97 & 0.32 & 3.28 & Indicated \\
\hline
\end{tabular}

The value of $\mathrm{z}$ to denote the parties at the level of $0.05=1.96$

Table (5) shows that under study in the skilled there are statistically performance in the research significant differences between the average of the pre and post measurements of the sample

\section{Table (6)}

Percentage improvement between the pre and post measurements of the sample in question the skillful performance is under consideration $\mathrm{N}=12$

\begin{tabular}{|c|c|c|c|c|c|c|}
\hline \multicolumn{2}{|c|}{ Variables } & $\begin{array}{c}\text { Measure } \\
\text { unit }\end{array}$ & $\begin{array}{c}\text { Pre } \\
\text { measure }\end{array}$ & $\begin{array}{c}\text { Post } \\
\text { measure }\end{array}$ & $\begin{array}{c}\text { Differences } \\
\text { between } \\
\text { the two }\end{array}$ & $\begin{array}{c}\text { improvement } \\
\text { rate }\end{array}$ \\
\hline \multirow{4}{*}{$\begin{array}{l}\text { Performance } \\
\text { skill }\end{array}$} & $\begin{array}{l}\text { Rolling front } \\
\text { Rounded }\end{array}$ & Degree & 2.21 & 3.68 & 1.47 & $39.94 \%$ \\
\hline & $\begin{array}{l}\text { The front roll and } \\
\text { the body are free }\end{array}$ & Degree & 2.18 & 3.88 & 1.70 & $43.81 \%$ \\
\hline & $\begin{array}{l}\text { Instantaneous } \\
\text { stand } \\
\text { On the hands }\end{array}$ & Degree & 2.63 & 3.94 & 1.31 & $33.24 \%$ \\
\hline & $\begin{array}{ll}\text { Rolling } & \text { back } \\
\text { Rounded } & \end{array}$ & Degree & 2.21 & 3.97 & 1.67 & $44.33 \%$ \\
\hline
\end{tabular}


Table (6) shows that the percentage of improvement of the percentage of the pre and post measurements of the sample in question in the skilled performance in question ranged from (33.24\%: $44.33 \%$ ), indicating that the program has a positive effect on the variables under consideration.

Second: Discussion of the Results:

It is clear from Table (6) that there are statistically significant differences between the average of pre and post measurements in motor intelligence and in the direction of telemetry. This researcher aims to perform the gymnastics program which contains exercises to improve the transitional movements through constant balance exercises by walking with ropes, High heels and feet on the ground, where mentally disabled children often find it difficult to coordinate sensory inputs during movement.

This is consistent with Essam El Din Ali (2008), (13) and Hamel BC, van Brookhaven H (2000) (18) that when isolating the sense of sight, the other senses will be involuntary, such as touch and motor sense that depends on standing on the ankles and feet Together in collaboration to achieve the required responses in difficult situations.

It is also clear from

Table (7) that there is an improvement in the level of motor intelligence and in the direction of telemetry. The researcher aims to use the gymnastics program to help focus attention in determining certain colors and dazzling inside the proposed games such as balls, ropes, plastic bands, balloons and bottles.

The ability to remember the performance of certain exercises with certain tools and the connection between them led to the distinction between the tools and their use and their colors and movements and thus helps the disabled child to participate in the performance of real and imagined movements of saturation of the disposition and desires and linked this whole process of thinking before Ed Exercise and after a period of time.

The researcher believes that during the exercise of gymnastics games by throwing balls and receive them between 
colleagues and drop the ball on the ground forward and kick the ball to the foot and back and also performed exercises walking and circling around the ring and rope and the circle and the use of different sounds (siren - applause) to distinguish a certain movement when hearing a particular voice These exercises improved the level of motor intelligence.

This is consistent with Essam El Din Ali (2008), (8) and Rahab Mabrouk (2006). (6) The proposed gymnastics program, which contains a variety of collective games that develop the spirit of teamwork and cooperation as well as competitions that help to

These children are in a positive direction with a distance from aggression and violence as well as contain the program on a large number of small tools in various shapes and colors are working to attract the attention of children and increase their motivation to work.

Because learning to work happens through physical movement, the body knows ways to perform many tasks, such as riding a bike, dancing, moving a body, taking something extruded, balancing while walking, learning keys on the computer's writing board, (74: 4) (41:22) It is a kind of physical, motor intelligence.

Issam Shaaban (2008) notes that learners with motor intelligence excel in physical activities, in visual-motor coordination, and have great tendencies for movement and touch of objects, ability to exercise or practice dance and acting, . This intelligence is based on the interaction of physical and motor configurations and abilities. This type of intelligence exists in the cerebellum and the primary neural mass. This intelligence develops from childhood and may appear at an advanced stage. It is influenced by the opportunities for training and practice in the environment and learns both on Sporting performance or motor performance. (9: 8)

Thus, the first hypothesis of the research, which states that there are statistically significant differences between the pre and post indices in the level of motor intelligence of the 
disabled and for the measurement of the dimension As shown in Table (8), there are statistically significant differences between the average of the pre and the post measurements in some of the skillful performances of the gymnasiums and in the direction of the telemetry. The researcher pointed out that the program exercises have a collective performance.

Each student has the opportunity to participate with others in bringing tools and using them And engaging together and direct friction for longer periods in a group work, which stimulates the student to $\begin{aligned} & \text { identify the form of } \\ & \text { performance with the } \\ & \text { colleague. }\end{aligned}$

This is consistent with Abdul Hamid Sharaf (2003) that sports is one of the pre of preparing the child well to contain games that distinguish the extent of the child's ability to master the skills of motor in a manner characterized by thrill and pleasure and not feeling tired and bored, which leads to better progress of the child than formal exercises (13:10.)

And that ground movements develop the ability to use parts of the body, whether on the ground or in the vacuum and these capabilities contribute effectively to raise the level of skilled performance and is a fertile ground to teach many similar skills to the rest of the other devices. (55:14)

The researcher believes that this improvement in the level of motor perception of the skills of gymnastics for the performance of skill is due to the program gymnastics of the proposed games, including the basic skills of walking and the process of halting and other through a group of exercises and games in an easy and exciting with the use of miscellaneous tools that attracted the attention of children and motivated to work with pleasure The second hypothesis, which states that there are statistically significant differences between the pre and post standards in the level of motor skills of children with mentally handicapped who can learn for the benefit of telemetry

\section{Conclusions:}

Within the objective of the research and in light of hypotheses and methodology used and through statistical analysis, the researcher reached the following conclusions:

-The proposed program using game gymnastics has improved the level of motor intelligence (dropping the ball around the circle - the colored ruler and the hands - the sound and 
movement - walk to the circle) mentally handicapped.

-The proposed program, using gymnastics games, improved the level of motor skill performance (front-wheel drive, front-wheel drive, openair stand-up, rear-wheel drive, total motor performance)

\section{Recommendations}

-Develop the proposed program for gymnastics in the curricula of physical education in schools of intellectual education because it has a positive effect on the effective development of motor intelligence mentally disabled students.

-Focus on the gymnastics programs of the Games and especially the different tools in the schools of intellectual education for the mentally handicapped who can learn at all stages.

-Conducting similar studies of mentally disabled children on other variables.

\section{References}

1- Abdel- Azim Shehata (2000): Vocational Rehabilitation of Mentally Retarded Persons, Dar AlNahda Al-Arabiya, Cairo.

2- Abdel- Hamid Sharaf (2003): "Physical and motor education for the most vulnerable and disabled children, the book center for publishing, Cairo.

3- Abdul Sattar Ibrahim and Abdul Aziz Al-Dakhil (2003): Behavioral Therapy for the Child "Methods and Models of His Cases", World of Knowledge Series, No. 180, National Council for Culture, Arts and Literature, Kuwait.

\section{4- Adil Saad Shenouda,} Samia Farghali Mansour (2002): "Artistic Gymnastics, Concepts, Applications", Forum of Thought, Alexandria.

\section{5- Ahmed Ezzat Qardash} (2004): Teaching Skills for Teachers with Special Needs, Theory and Practice, I 1, The Book Center for Publishing, Cairo.

6- Amal Mohamed Morsi (2006): "The Effect of a Training Program in the Tools of the Segregation and Segregation Systems on Social Interactions and the Communication Concern of Down Syndrome Children with Learning Disabilities, Sports Science and Arts, Physical Education for Boys, vol. 25, no. 3, July, Helwan University. 7-Cheers Mahmoud Tolba (2007): A personal study of the 
consensual behavior of mentally handicapped gifted athletes, the gifted conference, Cairo.

\section{8- Essam El-Din Shaaban Ali} (2008): Assessment of motor intelligence for the mentally disabled, published research, Iraqi Academy, Iraq.

9- Fawzi Rizkallah, Adel Abdul Basir (2000): theories and scientific foundations in training gymnastics, Modern Book House, Cairo.

10- Hadeel Ahmed Metwally (2015): "A proposed program for gymnastics and the improvement of some basic movements and social skills of talented children in the stage of kindergarten" Journal of applications of sports science, Faculty of Physical Education for Boys, No. (31) January University of Alexandria.

11-Hamel BC, van bokhoven H, et al. (2010). " X-linked mental retardation associated with cleft lip/palate maps to Xp 11.3-q21.3. " Am.J. med. Cenet. 85 (3) : 216-22

12- Ibrahim Abbas Zuhairi (2003): the philosophy of education of people with special needs and their education systems, Zahraa East Library. 13-john, m,\& Karin.h (1999): "The effects of physical conditioning exercises on the mental characteristions of educationally subn normal boys bitisl,journal of educational psychology.

14- Kerker, Bonnie D., et al. (2004): "Mental Health Disorders among Individuals with Mental Retardation,Challenges to Accurate Prevalence Estimates, Public Health Reports ,August. 409-17

15-Manar Shahin AbdelRahman, Omaima Hassanein Hegazi (2003) Effect of gymnastics program for games on physical adaptation and attention disorders and social interactions of autistic child, specialized scientific journal of sports education, Faculty of Physical Education, Assiut University.

16- Manar Abdulrahman

Shahin (2015) The impact of a proposed program for gymnastics and inhibitions to reduce the excessive activity and some psychotropic abilities of children of learning difficulties, published scientific research, Journal of Science and Mathematical Arts, Faculty 


\section{5}

of Satisfactory Education, Assiut University.

17- perheriness thomes .glatt, frank ingje (2003)r: 'High intensity with directel bicycle pedal improves performance in mechanically unstable ankle ,journal of medicine, vol (19), no (4), augst.

19- Rehab Mustafa Mabrouk (2006): "The Effect of a Proposed Kinetics Program on Some Behavioral Disabilities and the Cognitive Cognition of Mentally Disabled Persons", Journal of Sport Science and Arts, Physical Education for Boys, Vol 25, no. 3, July, Helwan University.
20- Safwat Faraj and Nahed Ramzi (2007): The measure of harmonic behavior Part II, inconsistent behavior, AngloEgyptian Library, Cairo.

21- Sayed Sobhy (2000):

Mental disability, studies in mental health, Medina, Saudi Arabia.

22- Suzanne Nottingham (2000): Training For Proprioception” ,Fitness Management Magazine, Vol (4), No (3), (P221-226)

23- Zainab Mahmoud Shoukair (2002): "Services for People with Special Needs", Part 3, The Egyptian Renaissance Library, Cairo. 